\title{
TERRITORIALIZAÇÃO DO COMPLEXO EUCALIPTO-CELULOSE-PAPEL E RESISTÊNCIA CAMPONESA EM TRÊS LAGOAS - MS
}

\author{
Leandro Reginaldo Maximino Lelis \\ Doutorando no Programa de Pós-Graduação e Pesquisa em Geografia da UFRN \\ sukko51@hotmail.com \\ Francisco José Avelino Júnior \\ Docente do Programa de Pós-Graduação em Geografia da UFMS/CPTL \\ china.ufms@hotmail.com
}

Recebido em: 28/10/2015; Aceito para publicação em: 18/03/2016

\begin{abstract}
RESUMO
A territorialização do complexo eucalipto-celulose-papel, no município de Três Lagoas, ocorreu em meados da década de 2000, provocando intensa reestruturação espacial, produtiva e econômica, além de diversos impactos socioambientais. Destarte, este trabalho tem como objetivo analisar a resistência camponesa frente à territorialização do complexo em questão no município pesquisado. Para tanto, foram realizados os seguintes procedimentos metodológicos: pesquisa e leitura do material bibliográfico selecionado; coleta e análise dos dados de fontes secundárias; e, trabalho de campo para aplicação de questionário junto aos camponeses de Três Lagoas. Constatou-se que, apesar das dificuldades, a maioiria dos camponeses pesquisados pretende ficar no campo, evidenciando a resistência camponesa perante às adversidades impostas pela territorialização do capital, representado, em Três Lagoas, pelo complexo eucalipto-celulose-papel.
\end{abstract}

Palavras-chave: territorialização do capital; complexo eucalipto-celulose-papel; resistência camponesa; Três Lagoas.

\section{TERRITORIALIZATION OF EUCALYPTUS-CELLULOSE-PAPER COMPLEX AND PEASANT RESISTANCE IN TRÊS LAGOAS - MS}

\begin{abstract}
The territorialization of eucalyptus-cellulose-paper complex in municipality of Três Lagoas occurred in the mid-2000s, causing intense spatial, productive and economic restructuring, besides several social and environmental impacts. Thus, this paper aims to analyze the peasant resistance against the territorialization complex in question in the searched municipality. Therefore, the following methodological procedures were performed: search and read the selected bibliographic material; collection and analysis of data from secondary sources; and fieldwork for application of questionnaire to Três Lagoas peasants. It was found that despite the difficulties majority of searched peasants plans to stay in the field, showing the peasant resistance against the adversities imposed by the territorialization of capital represented in Três Lagoas by the eucalyptus-cellulose-paper complex.
\end{abstract}

Keywords: territorialization of capital; eucalyptus-cellulose-paper complex; peasant resistance; Três Lagoas. 


\section{INTRODUÇÃO}

Durante muito tempo, o Cerrado brasileiro foi considerado sinônimo de probreza. Tal situação foi alterada, principalmente, a partir da década de 1970. No decorrer desta década, o Estado brasileiro incentivou o processo de territorialização do capital com o intuito de proporcionar a expansão da agricultura moderna no Cerrado. A referida modernização foi realizada com o intuito de inserir o Cerrado brasileiro nas demandas da economia internacional (CHAVEIRO e CALAÇA, 2012).

A expansão do monocultivo de eucalipto e das indústrias ligadas ao setor, em Três Lagoas, ocorreu em duas fases. A primeira fase iniciou-se na década de 1970 e encerrou-se na década de 1980, em função do fim dos incentivos fiscais (KUDLAVICZ, 2011). A segunda e atual fase iniciou-se em meados da década de 2000 e está em pleno processo de expansão. Em ambas as fases o Estado sempre esteve presente na viabilização da expansão dos eucaliptais. Todavia, na atual fase, o Estado se faz ainda mais presente, haja vista que através de incentivos fiscais e subsídios financeiros, contribuiu para a instalação de grandes indústrias ligadas à produção de celulose e papel. Além do Governo Federal, os governos estadual e municipal também exerceram papel fundamental para viabilizar a territorialização do complexo eucalipto-celulose-papel na localidade estudada (ALMEIDA, 2012; PERPETUA, 2012).

Neste contexto, este trabalho tem como objetivo analisar a resistência camponesa frente à territorialização do complexo eucalipto-celulose-papel em Três Lagoas. Para a consecução do objetivo proposto, realizaram-se os seguintes procedimentos metodológicos: pesquisa bibliográfica e leitura do material selecionado; coleta e análise dos dados de fontes secundárias; e, trabalho de campo para aplicação de 25 questionários. A pesquisa bibliográfica ocorreu acerca dos seguintes temas: territorialização do capital no Cerrado brasileiro; resistência camponesa; e, expansão do monocultivo de eucalipto em Três Lagoas. Os dados de fontes secundárias foram obtidos junto ao Instituto Brasileiro de Geografia e Estatística (IBGE) e à Comissão Pastoral da Terra (CPT). Os trabalhos de campo foram realizados nos dias 9 e 10/04/2015. Foram aplicados 25 questionários semiabertos, sendo 9 questionários no Assentamento Pontal do Faia, 8 no Distrito de Arapuá e 8 no Assentamento 20 de Março. Além dos questionários, um gravador de voz foi utilizado com o intuito de capturar os depoimentos dos camponeses pesquisados. Os locais de aplicação dos questionários foram diversificados com o objetivo de conhecer amplamente a realidade dos camponeses treslagoenses.

\section{A TERRITORIALIZAÇÃO DO CAPITAL NO CERRADO BRASILEIRO}

O município de Três Lagoas está localizado em uma área de Cerrado, no estado de Mato Grosso do Sul. Durante muito tempo, o Cerrado foi apontado como sinônimo de pobreza. Tal situação foi alterada, principalmente, a partir da década de 1970. Nesse período, o poder estatal, com apoio do capital privado nacional e internacional, implantou medidas com o intuito de inseri-lo nas demandas da economia internacional (CHAVEIRO e CALAÇA, 2012).

Por meio de políticas planejadas para o campo brasileiro, o Estado determinou 0 direcionamento da territorialização do capital. No Cerrado, esse direcionamento ocorreu a partir da década de 1970, com a criação das políticas do II Plano Nacional de Desenvolvimento (PND). A referida política pública possuía estratégias para ocupar economicamente o Cerrado, além de integrá-lo com outras regiões do Brasil (MATOS e PESSÔA, 2011).

Alguns programas foram criados com o intuito de viabilizar a territorialização da agricultura moderna no Cerrado. O Programa de Desenvolvimento dos Cerrados (POLOCENTRO) e o Programa de Cooperação Nipo-Brasileira para Desenvolvimento dos Cerrados (PRODECER) foram os programas de maior destaque do ponto de vista da inserção de capital e tecnologia (MATOS e PESSÔA, 2011).

Ressaltando o papel exercido pelo Estado para viabilizar a territorialização do capital e a consolidação da agricultura moderna no Cerrado, Matos e Pessôa (2011, p. 305) pontuam:

$\begin{array}{lllll}\text { Caminhos de Geografia } \quad \text { Uberlândia } \quad \text { v.17, n. 58 Junho/2016 } & \text { p. 81-102 } & \text { Página } 2\end{array}$


[...] o Estado teve participação ativa por meio de incentivos fiscais, crédito agrícola, subsídios à exportação e investimentos em infraestrutura, como, eletrificação rural, implantação de sistemas de beneficiamento e armazenamento de produtos agrícolas e construção de rodovias pavimentadas e não pavimentadas. Todos esses fatores possibilitaram a captura das áreas de Cerrado na e para a dinâmica da expansão capitalista de produção. Na verdade, as políticas agrícolas, conforme afirma Mendonça (2004), abrem caminho para o capital nas áreas de Cerrado.

A territorialização do capital alterou a dinâmica econômica estagnada do Cerrado para uma área de prosperidade econômica. Dessa mesma forma, a natureza foi modificada, pois passou de um lugar preservado para uma área onde as espécies são destruídas. Além disso, também ocorreram mudanças no modo de vida dos povos cerradeiros, principalmente daqueles que habitam o campo, já que estes passaram a viver em função de uma nova lógica. Nesse sentido, Chaveiro e Calaça (2012, p. 195) salientam:

Por esse viés, a ação do capital sobre o Cerrado ou o que Calaça (2010) chama "territorialização do capital" impacta o mundo dos sujeitos que aqui viviam - e vivem - criando modos de desenraizá-los, alterando seus modos de vida, interferindo em seus valores e em sua cultura.

De acordo com Porto-Gonçalves (2004), o Cerrado brasileiro e sua enorme diversidade biológica e cultural vêm se transformando numa área propícia para a expansão de grandes latifúndios produtivos. Essa expansão ocorre em função das inúmeras vantagens existentes riqueza hídrica, topografia plana etc. - nesse bioma. Segundo o autor, em 2004, estimava-se que $70 \%$ da área das chapadas estavam ocupadas pelo agronegócio, pelo "[...] cultivo de grãos, algodão ou de monoculturas de plantação de madeira [...]" (PORTO-GONÇALVES, 2004, p. 223).

Conforme Canuto (2004), o ecossistema Cerrado ocupa um quarto do território brasileiro, além de ser o mais ameaçado pela expansão do agronegócio. O Cerrado também é qualificado como a savana mais rica do mundo, no que diz respeito à biodiversidade. Entretanto, apenas $2 \%$ de seu território está protegido na forma de Unidades de Conservação, demonstrando a vulnerabilidade deste bioma perante o avanço do agronegócio. O Cerrado também possui enorme riqueza hídrica, com nascentes de importantes rios brasileiros, como: Araguaia, São Francisco, Paraná, Tocantins, entre outros. Sobre a expansão desenfreada do agronegócio no Cerrado brasileiro, Canuto (2004, p. 10) escreve:

\begin{abstract}
O agronegócio é devastador. Imensas áreas de florestas e do cerrado estão sendo ilegalmente desmatadas, secando nascentes e mananciais, sugados pelo ralo das monoculturas, pastos de capim, carvoarias, mineradoras e madeireiras. Os agrotóxicos, despejados por aviões e tratores, estão contaminando solos, águas, ar e as plantações camponesas, causando doenças e mortes.
\end{abstract}

A nova lógica que passou a reger o Cerrado, baseada nas demandas da economia internacional, provocou uma mudança estrutural. O modelo tradicional e característico do Cerrado perdeu espaço, pois, a partir da territorialização do capital, o modelo moderno, liderado pela monocultura e pela pecuária intensiva, passou a ser seguido no território cerradeiro. Nesse sentido, Chaveiro e Calaça (2012, p. 195) corroboram: "a inserção do Cerrado na economia internacional, a um só tempo, substitui a economia de subsistência baseada no modelo fazenda e roça para o da monocultura de soja e pastagem".

$\begin{array}{lllll}\text { Caminhos de Geografia } \quad \text { Uberlândia } \quad \text { v.17, n. } 58 \quad \text { Junho/2016 p. 81-102 } & \text { Página } 3\end{array}$


A respeito das alterações estruturais proporcionadas pela expansão da agricultura moderna no Cerrado, Matos e Pessoa (2009) salientam que as áreas inseridas no processo de territorialização do capital têm passado por

[...] mudanças radicais em sua organização produtiva, social e ambiental. No setor produtivo, são inseridas novas culturas e novos métodos de produção agregado aos conteúdos das tecnologias. O social é atingido sob vários aspectos, mas especialmente, pela exclusão de muitos produtores rurais do processo produtivo e pelos desdobramentos ambientais que vão desde a destruição da fauna e flora até dos recursos hídricos (MATOS e PESSOA, 2009, p. 9).

Em relação aos impactos ambientais, Calaça (2010) aponta que ao criar condições para a expansão da biotecnologia, o processo de territorialização do capital favorece a substituição da vegetação nativa por espécies agrícolas. Tal substituição acarreta em prejuízo ambiental enorme em decorrência da redução da diversidade de plantas e animais.

Para Calaça (2010), o processo de modernização agrícola e a consequente incorporação da biotecnologia no campo foram responsáveis por alterar "[...] as práticas agrícolas, as relações sociais de produção, a interação com a natureza, modificando as práticas dos camponeses e dos agricultores tradicionais do Cerrado" (CALAÇA, 2010, p. 16).

Baseado em dados da Organização das Nações Unidas para Alimentação e Agricultura (FAO), Porto-Gonçalves (2004) aponta que nos últimos cinquenta anos, a produção de grãos aumentou três vezes enquanto que o uso de fertilizantes foi multiplicado quatorze vezes.

A expansão exponencial do uso de adubos e fertilizantes, herbicidas, pesticidas e fungicidas vem sendo há décadas objeto de intensas críticas de ambientalistas, de órgãos ligados à saúde e de sindicatos de trabalhadores sobretudo rurais (PORTO-GONÇALVES, 2004, p. 225).

Tal situação implica em inúmeros prejuízos ambientais causados pela poluição oriunda desses insumos. Dessa forma, os recursos hídricos, o ar, o solo, a vegetação e os seres humanos são afetados pela utilização demasiada dos insumos agrícolas.

Kudlavicz (2011) salienta que o uso intensivo de herbicidas e agrotóxicos são consequências da expansão do modelo agrário-agrícola exportador baseado na monocultura. Ainda para 0 autor supracitado, esse uso intensivo pode causar danos irreparáveis para o meio ambiente, contribuindo para a simplificação dos ecossistemas e para a diminuição da biodiversidade.

O processo de territorialização do capital não ocorreu com a mesma intensidade em todas as partes do Cerrado, pois algumas áreas atraíram mais a atenção do capital, enquanto outras ficaram às margens desse processo. A respeito das áreas escolhidas ou não para a territorialização do capital, Chaveiro a Calaça (2012, p. 195) pontuam:

\footnotetext{
Além da posição territorial, especialmente a aproximação com os centros de economia hegemônica como o Sul e o Sudeste do país, os contextos históricos de cada lugar, ou os espaços herdados, participam direta - e decisivamente - da escolha estratégica para a territorialização do capital.
}

Deste modo, a territorialização do capital não ocorreu da mesma maneira e com a mesma intensidade em todos os lugares, haja vista que modelos de produção mais antigos coexistem com modelos modernos. Além da existência de outros modelos de produção, outros modelos de relações sociais também continuam existindo mesmo após a intensificação da ação do capital no campo. Neste sentido, Lima (2012, p. 142) afirma: "no interior do processo de

$\begin{array}{lllll}\text { Caminhos de Geografia } \quad \text { Uberlândia } & \text { v.17, n. 58 } & \text { Junho/2016 } & \text { p. 81-102 } & \text { Página } 4\end{array}$


territorialização do capital há a criação, destruição e recriação do trabalho familiar camponês, pois o capitalismo não é capaz de conter apenas um modelo de relação social".

Chaveiro e Calaça (2012) apontam que nas últimas décadas a expansão do capital no campo ocorreu em diversos estados brasileiros que possuem o bioma Cerrado - Goiás, Minas Gerais, Mato Grosso, Mato Grosso do Sul, dentre outros -, e que essa expansão provocou conflitos "[...] entre a territorialização do capital em escala global e as territorialidades locais [...]" (CHAVEIRO e CALAÇA, 2012, p.197).

No campo, esses conflitos ocorrem "[...] entre os proprietários/capitalistas enquanto personificação do agronegócio na busca de terras de exploração e o campesinato protagonista central na luta de classe na busca da terra como condição de vida" (LIMA, 2012, p. 139). Sendo assim, de um lado está o agronegócio como produto do capital, enquanto do outro aparece o campesinato evidenciando as territorialidades locais.

Além das dificuldades citadas para o desenvolvimento socioeconômico dos povos cerradeiros no campo, Matos e Pessoa (2009) apontam que o Estado pouco considerou a importância desses povos durante o processo de modernização das atividades agropecuárias no Cerrado, tendo em vista que "os incentivos por meio de financiamentos, programas e infra-estruturas eram voltados principalmente para os produtores sulistas que já possuíam tradição e experiência na agricultura moderna" (MATOS e PESSOA, 2009, p. 10).

O processo de territorialização do capital no Cerrado, principalmente a partir da década de 1970, proporcionou impactos socioambientais significativos. Apesar do contexto desfavorável, os camponeses continuam resistindo às adversidades impostas pela territorialização do capital, conforme poderá ser verificado no decorrer desta pesquisa.

\section{RESISTÊNCIA CAMPONESA E OS CONFLITOS NO CAMPO}

Oliveira (1996a) afirma que as transformações estruturais do campo brasileiro, principalmente a partir da década de 1960, têm desencadeado as lutas pela terra. Para Oliveira (1996b), essas transformações foram responsáveis pelo "[...] aumento significativo dos movimentos sociais rurais, em luta pela terra ou por melhores condições de trabalho" (OLIVEIRA, 1996b, p. 523).

Segundo Fabrini (2010), por meio das lutas realizadas pelos movimentos sociais rurais, com destaque para as ocupações de terra e acampamentos, os camponeses resistem ao projeto de "desenvolvimento" para o campo brasileiro viabilizado pelo capital.

A ocupação sempre esteve entre as estratégias utilizadas pelos camponeses para lutar pela terra, conforme afirma Fernandes (2000, p. 286): "a ocupação, como forma de luta e acesso a terra, é um contínuo na história do campesinato brasileiro. Desde o princípio de sua formação, os camponeses, em seu processo de criação e recriação, ocuparam terra".

Fabrini (2011) aponta que ao participarem dos movimentos sociais os camponeses resistem às perversidades impostas pelo capitalismo.

Diante desse contexto, os camponeses organizados nos movimentos sociais [...] resistem bravamente ao projeto de desenvolvimento das oligarquias e empresários rurais, indicando que os conflitos sociais são também conflitos territoriais: o território do agronegócio e latifúndio em contraposição ao território camponês. Acrescenta-se que o território camponês é portador de um conjunto de práticas não-capitalistas, como produção de autoconsumo e resistência, controle relativo do processo produtivo, autonomia, relações comunitárias e solidárias, dentre outras (FABRINI, 2011, p.110).

De acordo com Bedun (2012), a luta pela terra evidencia a resistência camponesa à expropriação, violência, exploração e sujeição provocadas pelo desenvolvimento do capitalismo no campo. Ainda para a autora: "as diversas manifestações e lutas desenvolvidas no campo

$\begin{array}{llllll}\text { Caminhos de Geografia } \quad \text { Uberlândia } \quad \text { v.17, n. } 58 \quad \text { Junho/2016 } & \text { p. 81-102 } & \text { Página } 5\end{array}$


pelos camponeses apontam para uma idéia de resistência e (re) criação contra a expropriação regida pela lógica capitalista" (BEDUN, 2012, p. 40).

Fabrini (2010) afirma que os assentamentos de reforma agrária são resultados importantes das lutas dos movimentos sociais rurais. Para o autor supracitado, os assentamentos de reforma agrária constituem-se como importantes frações do território camponês. Ainda segundo o autor, nesses territórios camponeses, antigas e novas sociabilidades são reavivadas e recriadas a partir da conquista da terra.

A respeito da luta dos movimentos sociais pela reforma agrária, Fernandes $(2008$, p. 76$)$ afirma que: "[...] lutar pela reforma agrária, significa lutar por todas as dimensões do território, entre elas a tecnologia, o mercado, a educação, saúde e, principalmente, contra o capital que procura tomar o controle dos territórios do campesinato".

Destarte, de acordo com Almeida (2006), a luta pela terra deve ser entendida como uma luta contra o capital, tendo em vista que uma reforma agrária de caráter apenas distributivo mantém a renda subjugada ao capitalista, mantendo a sujeição do trabalhador camponês perante 0 capital. Para Oliveira (1995, p. 81): "[...] a luta pela terra não pode-se restringir apenas e especificamente, à luta pelo direito do acesso à terra; deve, isto sim, ser a luta contra quem está por trás da propriedade capitalista da terra, ou seja, o capital".

Ao lutarem pela terra e pela reforma agrária, os movimentos sociais rurais "[...] têm se desenvolvido na contramão do discurso desenvolvimentista respaldado pelo agronegócio e apregoado pelo capital" (BEDUN, 2012, p. 59). Nesta situação:

\begin{abstract}
As elites concentradoras de terra respondem com a barbárie. Assim, o país vai prosseguindo no registro das estatísticas crescente sobre os conflitos e a violência no campo. A luta sem trégua e sem fronteiras que travam os camponeses e trabalhadores do campo por um pedaço de chão e contra as múltiplas formas de exploração de seu trabalho amplia-se por todo canto e lugar, multiplica-se como uma guerrilha civil sem reconhecimento. Essa realidade cruel é a face da barbárie que a modernidade gera no Brasil (OLIVEIRA, 2007, p. 151-152).
\end{abstract}

Os conflitos existentes no campo, sobretudo, os oriundos das disputas entre os camponeses e o capital, evidenciam a luta dos movimentos sociais pela terra e "[...] o enfrentamento do camponês a uma estrutura agrária calcada na concentração fundiária e monopolizada pelo capital" (BEDUN, 2012, p. 49-50). Assim, as divergências existentes entre a classe camponesa e a classe capitalista têm se desdobrado em violência no campo brasileiro, onde o capital persegue e aterroriza o trabalhador camponês (BEDUN, 2012).

No que se refere à disputa territorial entre o capital e o campesinato, Paulino e Almeida (2010, p. 58) constatam: "de um lado, a classe daqueles que usam a terra para extrair renda e lucro e produzir dominação política; do outro, a classe dos camponeses que da terra precisam para viver. O resultado tem sido um território em disputa!".

As disputas territoriais entre o campesinato e o capital indicam lógicas divergentes de organização e produção no campo. Enquanto o camponês desenvolve suas atividades na propriedade familiar e produz de maneira diversificada para satisfazer suas necessidades básicas, o capitalista "[...] organizado na grande propriedade fundiária, baseada na monocultura exportadora, vive do lucro, fruto da exploração da força de trabalho" (BEDUN, 2012, p. 90-91).

Os conflitos territoriais entre o capital e o campesinato são responsáveis pela ampliação da violência no campo brasileiro. Para Girardi e Fernandes (2009, p. 363): "[...] a violência tem sido utilizada pelo latifúndio e pelo agronegócio para expropriar e impedir a territorialização e a reterritorialização do campesinato". Assim, a violência é utilizada pelos capitalistas para reprimir a luta camponesa pela terra. Nesse sentido, segundo Oliveira $(2007$, p.135) a "[...] violência tem sido a principal característica da luta pela terra no Brasil". A Tabela 1, por exemplo, apresenta os dados dos conflitos no Brasil entre os anos de 1990 e 2013. Entre os tipos de conflitos estão: conflitos por terra, conflitos por água, conflitos trabalhistas, entre outros.

$\begin{array}{llllll}\text { Caminhos de Geografia } \quad \text { Uberlândia } & \text { v.17, n. 58 } \quad \text { Junho/2016 } & \text { p. 81-102 } & \text { Página } 6\end{array}$


Tabela 1. Brasil: número de conflitos no campo (1990 - 2013)

\begin{tabular}{cccccccc}
\hline Ano & $\begin{array}{c}\text { No de } \\
\text { conflitos }\end{array}$ & Ano & $\begin{array}{c}\text { No de } \\
\text { conflitos }\end{array}$ & Ano & $\begin{array}{c}\text { № de } \\
\text { conflitos }\end{array}$ & Ano & $\begin{array}{c}\text { № de } \\
\text { conflitos }\end{array}$ \\
\hline $\mathbf{1 9 9 0}$ & 448 & $\mathbf{1 9 9 6}$ & 750 & $\mathbf{2 0 0 2}$ & 925 & $\mathbf{2 0 0 8}$ & 1.170 \\
$\mathbf{1 9 9 1}$ & 453 & $\mathbf{1 9 9 7}$ & 736 & $\mathbf{2 0 0 3}$ & 1.690 & $\mathbf{2 0 0 9}$ & 1.184 \\
$\mathbf{1 9 9 2}$ & 433 & $\mathbf{1 9 9 8}$ & 1.100 & $\mathbf{2 0 0 4}$ & 1.801 & $\mathbf{2 0 1 0}$ & 1.186 \\
$\mathbf{1 9 9 3}$ & 545 & $\mathbf{1 9 9 9}$ & 983 & $\mathbf{2 0 0 5}$ & 1.881 & $\mathbf{2 0 1 1}$ & 1.363 \\
$\mathbf{1 9 9 4}$ & 485 & $\mathbf{2 0 0 0}$ & 660 & $\mathbf{2 0 0 6}$ & 1.657 & $\mathbf{2 0 1 2}$ & 1.364 \\
$\mathbf{1 9 9 5}$ & 554 & $\mathbf{2 0 0 1}$ & 880 & $\mathbf{2 0 0 7}$ & 1.538 & $\mathbf{2 0 1 3}$ & 1.266 \\
\hline
\end{tabular}

Fonte: CPT (2015).

Os conflitos entre o agronegócio e o campesinato, no geral, tem se caracterizado pela barbárie e violência. Assim, esses conflitos têm custado vidas. A Tabela 2 apresenta os dados referentes ao número de assassinatos que ocorreram durante os conflitos no Brasil entre os anos de 1990 e 2013. Em 24 anos de conflitos, ocorreram 974 assassinatos.

Tabela 2. Brasil: número de assassinatos em conflitos no campo (1990 - 2013)

\begin{tabular}{lccccccc}
\hline Ano & Assassinatos & Ano & Assassinatos & Ano & Assassinatos & Ano & Assassinatos \\
\hline $\mathbf{1 9 9 0}$ & 79 & $\mathbf{1 9 9 6}$ & 54 & $\mathbf{2 0 0 2}$ & 43 & $\mathbf{2 0 0 8}$ & 28 \\
$\mathbf{1 9 9 1}$ & 54 & $\mathbf{1 9 9 7}$ & 30 & $\mathbf{2 0 0 3}$ & 73 & $\mathbf{2 0 0 9}$ & 26 \\
$\mathbf{1 9 9 2}$ & 46 & $\mathbf{1 9 9 8}$ & $\mathbf{4}$ & $\mathbf{2 0 0 4}$ & 39 & $\mathbf{2 0 1 0}$ & 34 \\
$\mathbf{1 9 9 3}$ & 52 & $\mathbf{1 9 9 9}$ & 27 & $\mathbf{2 0 0 5}$ & 38 & $\mathbf{2 0 1 1}$ & 29 \\
$\mathbf{1 9 9 4}$ & 47 & $\mathbf{2 0 0 0}$ & 21 & $\mathbf{2 0 0 6}$ & 39 & $\mathbf{2 0 1 2}$ & 36 \\
$\mathbf{1 9 9 5}$ & 41 & $\mathbf{2 0 0 1}$ & 29 & $\mathbf{2 0 0 7}$ & $\mathbf{2 8}$ & $\mathbf{2 0 1 3}$ & 34 \\
\hline
\end{tabular}

Fonte: CPT (2015).

De acordo com Bedun (2012), os conflitos existentes no campo brasileiro não são amplamente divulgados, "[...] uma vez que a história do Brasil sempre esteve voltada para a classe dominante, controlada por latifundiários e capitalistas, e não em torno da luta e mobilização da classe de trabalhadores" (BEDUN, 2012, p. 60).

Para Bedun (2012), as tensões e a violência presentes nos conflitos agrários são evidencias das contradições existentes na territorialização do capital no campo. Conforme a autora, as contradições do capitalismo refletem "[...] o processo de uso e exploração do território. Neste contexto, o camponês é atingido pela violência da subordinação, exploração e expropriação, a partir da lógica desigual e contraditória do capital" (BEDUN, 2012, p. 61).

Thomaz Júnior (2009) afirma que a violência utilizada pelos capitalistas e pelo Estado contra os movimentos sociais é uma marca dos conflitos agrários brasileiros.

O expediente da violência e da truculência adotados pelas classes dominantes e pelo próprio Estado sustenta marcas indeléveis, tanto no que se refere aos assassinatos, quanto às perseguições e desaparecimentos de trabalhadores (posseiros, assalariados, pequenos produtores, etc), dirigentes sindicais e militantes dos diversos movimentos sociais envolvidos na luta pelo acesso à terra e resistência nela (THOMAZ JÚNIOR, 2009, p. 85). 
Apesar da constante repressão e violência contra os trabalhadores camponeses, Thomaz Júnior (2009) aponta que essas barbáries não exterminaram o envolvimento e a luta dos trabalhadores pelo acesso à terra, por melhores condições no campo, dentre outros objetivos.

\begin{abstract}
Nesse sentido, a repressão e a violência que engordam as fatídicas estatísticas das torturas, dos assassinatos, dos desaparecimentos de camponeses, lideranças sindicais e trabalhadores rurais, bem como o comprometimento da maioria do Poder Judiciário com os imperativos do capital e do latifúndio, não fizeram desaparecer o envolvimento e a luta dos trabalhadores, sintonizados com o desejo do acesso a terra, à Reforma Agrária, às melhores condições de trabalho, ao cumprimento dos direitos trabalhistas, às denúncias de trabalho escravo etc. (THOMAZ JÚNIOR, 2009, p. 367).
\end{abstract}

Assim, mesmo com a violência utilizada pelos capitalistas, o campesinato segue sua trajetória de luta para entrar e permanecer na terra, resistindo às perversidades impostas pela territorialização do capital no campo.

\title{
A EXPANSÃO DO MUNOCULTIVO DE EUCALIPTO EM TRÊS LAGOAS
}

A expansão do monocultivo de eucalipto no município de Três Lagoas (Figura 1) ocorreu em duas fases. A primeira fase, que ocorreu na década de 1970, foi incentivada pelo Estado brasileiro no período do regime militar através do II Plano Nacional de Desenvolvimento (PND). O Programa de Desenvolvimento dos Cerrados (POLOCENTRO) e o Banco Nacional de Desenvolvimento Econômico e Social (BNDES) também exerceram papel fundamental para a expansão da silvicultura de eucalipto na região de Três Lagoas nessa primeira fase. Na década de 1980, devido ao fim dos incentivos fiscais, as plantações de eucalipto reduziram drasticamente (JURADO, 2008; KUDLAVICZ, 2011).

Figura 1. Três Lagoas - MS: localização geográfica

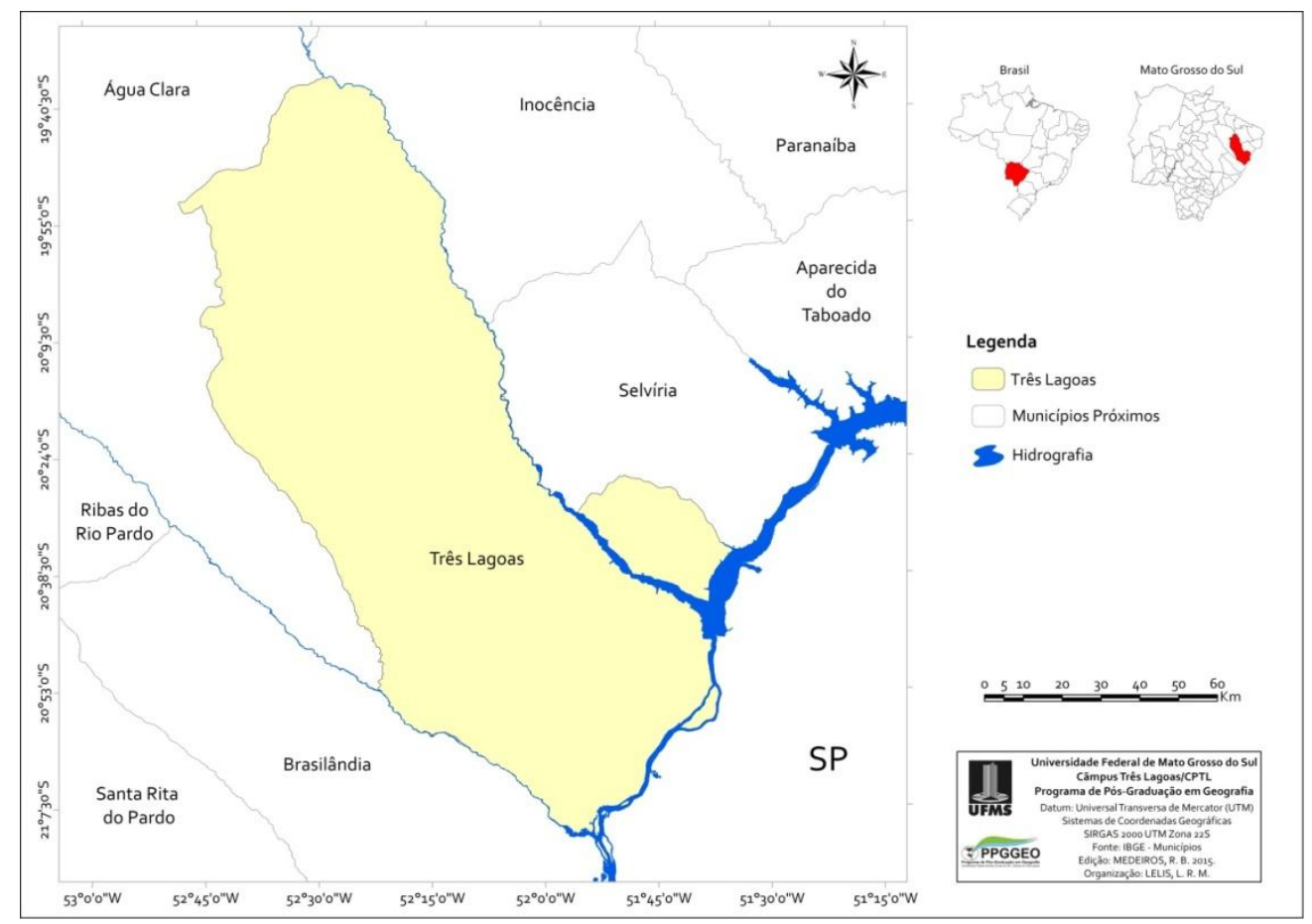

Fonte: IBGE (2015). Org.: LELIS (2015). 
A segunda fase de expansão dos eucaliptais ocorreu no período do governo de Luiz Inácio Lula da Silva (2003-2010). Por meio de recursos públicos, o governo incentivou a expansão do plantio de eucalipto para a produção de celulose e papel. A instalação de novas indústrias e a ampliação das indústrias já existentes também foi incentivada (KUDLAVICZ, 2011).

Kudlavicz (2011) aponta que nessa segunda fase os investimentos do BNDES também foram importantes para o setor florestal, já que envolveram grande montante financeiro com intuito "[...] de fortalecer a expansão da silvicultura e, principalmente, apoiar a modernização, ampliação e instalação de novas indústrias de celulose e papel" (KUDLAVICZ, 2011, p. 69).

Além do BNDES, Kudlavicz (2011) também enfatiza a relevância do Fundo Constitucional para o Centro-Oeste (FCO), haja vista que a linha de financiamento para o fomento florestal oferecida por esse fundo tem contribuído para o custeio de plantios de eucalipto. Esses investimentos no setor atraíram inúmeras indústrias ligadas ao monocultivo de eucalipto para 0 município de Três Lagoas.

A junção da Votorantim Celulose Papel (VCP) com a International Paper (IP) para a instalação do Complexo VCP-IP se constituiu como o arranque inicial para a instalação de indústrias de celulose e papel no município de Três Lagoas. A construção do complexo, denominado "Projeto Horizonte", ocorreu em três anos e custou cerca de $R \$ 3.880 .000 .000,00$, sendo grande parte financiada pelo BNDES (KUDLAVICZ, 2011; PERPETUA, 2012).

Em 2009, ano que o Complexo VCP-IP entrou em operação, uma junção com a Aracruz Celulose fez com que a unidade passasse a se chamar Fibria. Nesse mesmo ano, este complexo se tornou o maior produtor de celulose do mundo (KUDLAVICZ, 2011; PERPETUA, 2012).

Em 2010, a Eldorado Brasil anunciou a construção de sua fábrica em Três Lagoas. A empresa, controlada pelo Grupo JBS e pela MCL Empreendimentos, anunciou um projeto ainda mais audacioso que o projeto elaborado para a implantação do Complexo VCP-IP. Orçado em cerca de $\mathrm{R} \$ 5.100 .000 .000,00$, o "Projeto Eldorado" contou com $\mathrm{R} \$ 2.700 .000 .000,00$ financiados pelo BNDES. O empreendimento foi inaugurado em $2012 \mathrm{com}$ o intuito de se tornar a maior fábrica de celulose de fibra curta do mundo, superando a capacidade produtiva da Fibria. Para que tal intento fosse alcançado, suas instalações foram construídas para possuir capacidade produtiva de 1,5 milhões de toneladas por ano (PERPETUA, 2012).

Alguns fatores foram fundamentais para possibilitar a instalação das grandes empresas do setor de celulose e papel no município de Três Lagoas. Segundo Kudlavicz (2011), a grande disponibilidade de terras baratas e de água somado aos incentivos governamentais foram os principais responsáveis por essa atração. Kudlavicz (2011) também ressalta a importância da mão de obra barata e da fraca organização sindical como fatores que também contribuíram para a expansão das indústrias destinadas a produção de celulose e papel no referido município.

Perpetua (2012) aponta que existem diversas características que proporcionaram a territorialização do complexo eucalipto-celulose-papel em Três Lagoas (ALMEIDA 2010; 2012; KUDLAVICZ, 2011; PERPETUA, 2012). Embora os empresários ligados ao setor afirmarem que os principais fatores são os de ordem natural, para o autor supracitado, os principais fatores são sociais e políticos.

Do ponto de vista dos fatores naturais, os principais são: clima tropical; relevo suavemente ondulado, que possibilita o corte mecanizado; solos adequados para as florestas plantadas; relativa abundância de água superficial em virtude da proximidade com o Rio Paraná. Esse último fator se torna essencial em função de estudos que apontam que o processo produtivo da celulose consume uma quantidade elevada de água. Além dos fatores mencionados, acrescenta-se a localização geográfica privilegiada, já que Três Lagoas localiza-se no centro da América do Sul (PERPETUA, 2012).

Como informado anteriormente, apesar da importância dos fatores naturais, Perpetua (2012) acredita que são os fatores sociais e políticos os mais importantes para a expansão do monocultivo de eucalipto no município de Três Lagoas, dentre os quais se destacam:

$\begin{array}{llllll}\text { Caminhos de Geografia } \quad \text { Uberlândia } \quad \text { v.17, n. 58 } \quad \text { Junho/2016 } & \text { p. 81-102 } & \text { Página } 9\end{array}$


disponibilidade e baixo valor da terra; incipiente organização sindical; e, principalmente, apoio e empenho dos governos federal, estadual e municipal para a viabilização dos empreendimentos ligados ao complexo eucalipto-celulose-papel (PERPETUA, 2012).

Nesse contexto fica evidente que o Estado é o principal agente que atua proporcionando as condições necessárias para a expansão da silvicultura de eucalipto e das indústrias ligadas a este segmento em Três Lagoas, "[...] assegurando não apenas as garantias econômicas exigidas pelo grande capital (benefícios tributários e subsídios), mas também o acesso irrestrito aos recursos naturais (terra e água) presentes nessa porção do seu território" (PERPETUA, 2012, p. 177).

Para Almeida (2012), o Estado também é o grande responsável por viabilizar a expansão do complexo eucalipto-celulose-papel em Três Lagoas, já que este atuou "[...] como ordenador do território criando logísticas, disponibilizando créditos, flexibilizando a legislação ambiental" (ALMEIDA, 2012, p. 10).

A expansão do monocultivo de eucalipto pode ser constatada nas figuras 2 e 3 . A Figura 2 apresenta as áreas ocupadas pelos eucaliptais no ano de 2000.

Figura 2. Três Lagoas - MS: uso e ocupação da terra no ano de 2000

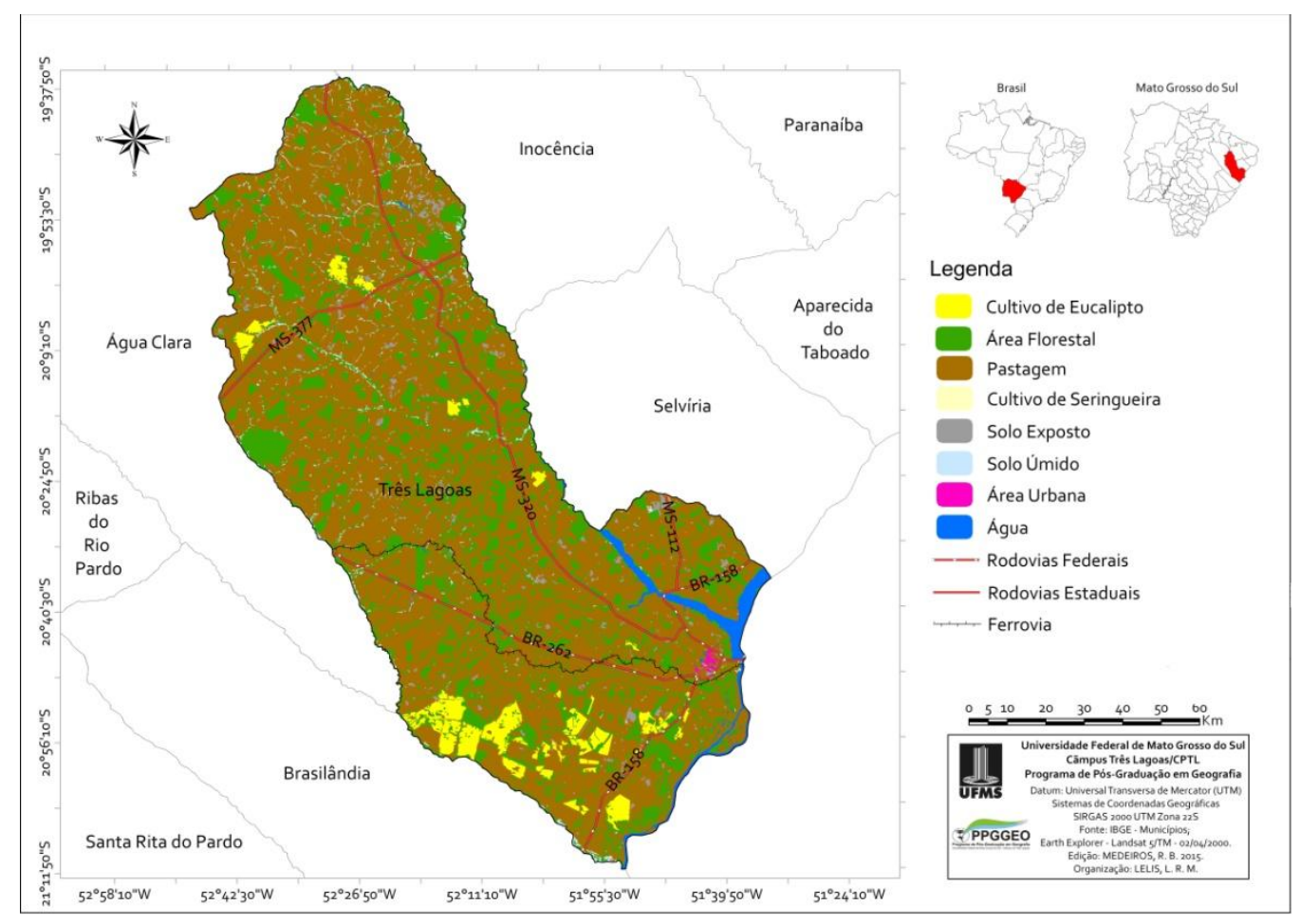

Fonte: IBGE (2015). Org.: LELIS (2015).

Conforme a Figura 2, em 2000, poucas áreas eram ocupadas pelos eucaliptais. No entanto, em 2013, nota-se significativa ampliação das áreas ocupadas pelo monocultivo de eucalipto (Figura 3). 
Figura 3. Três Lagoas - MS: uso e ocupação da terra no ano de 2013

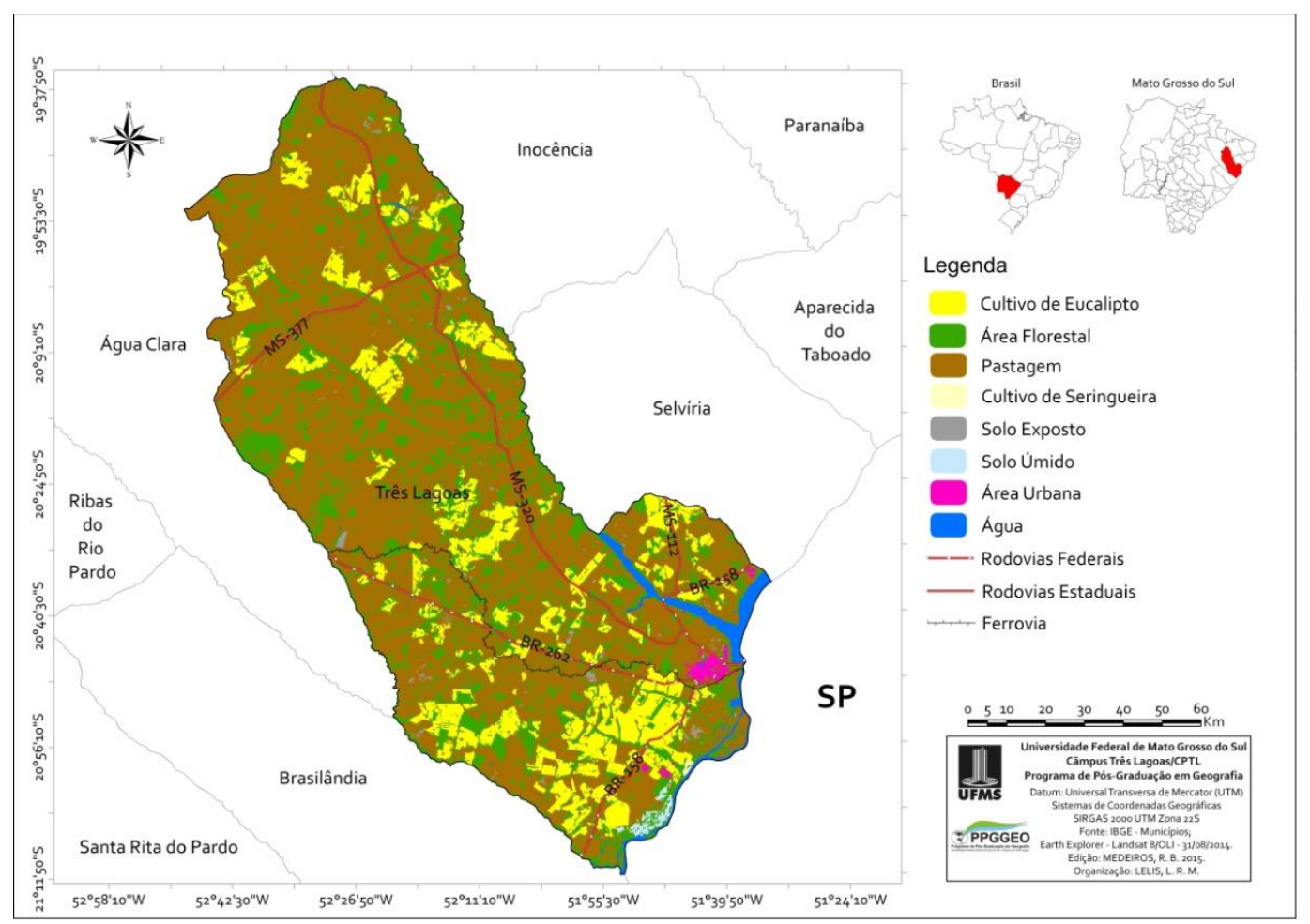

Fonte: IBGE (2015). Org.: LELIS (2015).

Os dados também confirmam a grandiosidade do monocultivo de eucalipto em Três Lagoas. A extração de madeira para produção de celulose e papel, por exemplo, apresentou crescimento vertiginoso nos últimos anos. Como apontando anteriormente, o crescimento desse setor econômico ocorreu, principalmente, em decorrência da instalação de indústrias produtores de celulose e papel. No ano de 2000 , por exemplo, não houve registro de extração de madeira para a produção de papel e celulose em Três Lagoas. A partir do ano de 2005, já vislumbrando a instalação da primeira unidade industrial destinada à produção de celulose e papel que ocorreria no ano de 2006, a extração de madeira para a produção de papel e celulose foi de 216.292 metros cúbicos. Em 2013, com a consolidação de duas grandes unidades industriais produtoras de papel e celulose, a extração de madeira para a produção de papel e celulose cresceu significativamente. Nesse ano, a extração de madeira para a produção de papel e celulose foi de 3.300 .655 metros cúbicos (Tabela 3). Comparando o ano de 2005, primeiro ano de registro da extração de madeira para a produção de celulose e papel, com o ano de 2013 , último ano do período analisado, verifica-se aumento percentual de $1.426 \%$.

Tabela 3. Três Lagoas - MS: quantidade extraída de madeira em tora para a produção de celulose e papel $(2000-2013)$

\begin{tabular}{lcccc}
\hline Tipo de silvicultura & $\mathbf{2 0 0 0}$ & $\mathbf{2 0 0 5}$ & $\mathbf{2 0 1 0}$ & $\mathbf{2 0 1 3}$ \\
\cline { 2 - 5 } & $\begin{array}{c}\text { Quantidade } \\
\text { (metros cúbicos) }\end{array}$ & $\begin{array}{c}\text { Quantidade } \\
\text { (metros cúbicos) }\end{array}$ & $\begin{array}{c}\text { Quantidade } \\
\text { (metros cúbicos) }\end{array}$ & $\begin{array}{c}\text { Quantidade } \\
\text { (metros cúbicos) }\end{array}$ \\
$\begin{array}{l}\text { Madeira em tora } \\
\text { para a produção de } \\
\text { cellulose e papel }\end{array}$ & - & 216.292 & 1.938 .487 & 3.300 .655 \\
\hline
\end{tabular}

Fonte: Produção da Extração Vegetal e da Silvicultura, IBGE (2015).

$\begin{array}{lllll}\text { Caminhos de Geografia } \quad \text { Uberlândia } \quad \text { v.17, n. 58 Junho/2016 } & \text { p. 81-102 } & \text { Página } 11\end{array}$


Outra evidencia da expansão significativa da silvicultura de eucalipto pode ser constatada na Tabela 4. Nessa tabela, estão disponíveis os dados referentes ao valor gerado pela extração de madeira em tora para a produção de celulose e papel. No ano de 2005 , o valor gerado pela extração de madeira em tora para a produção de papel ainda era incipiente se comparado com os valores gerados atualmente por esse setor econômico. Nesse ano, o valor gerado foi de $\mathrm{R} \$$ 6.398.000,00. Em 2013, esse valor aumentou para $\mathrm{R} \$ 181.536 .000,00$, evidenciando crescimento de $2.737,4 \%$.

Tabela 4. Três Lagoas - MS: valor gerado pela extração de madeira em tora para produção de celulose e papel $(2000-2013)$

\begin{tabular}{lcccc}
\hline Tipo de silvicultura & $\mathbf{2 0 0 0}$ & $\mathbf{2 0 0 5}$ & $\mathbf{2 0 1 0}$ & $\mathbf{2 0 1 3}$ \\
\cline { 2 - 5 } & Valor (mil reais) & Valor (mil reais) & Valor (mil reais) & Valor (mil reais) \\
$\begin{array}{l}\text { Madeira em tora } \\
\text { para a produção de } \\
\text { cellulose e papel }\end{array}$ & - & 6.398 & 114.371 & 181.536 \\
\hline
\end{tabular}

*Os dados do ano 2000 não foram disponiblizados pelo IBGE.

Fonte: Produção da Extração Vegetal e da Silvicultura - IBGE (2015).

Analisando a expansão das áreas ocupadas pelos eucaliptais e o crescimento significativo da quantidade produzida e do valor gerado pela produção de madeira em tora para produção de papel e celulose, constata-se que a expansão do monocultivo de eucalipto tem proporcionado intensa reestruturação espacial, produtiva e econômica no município de Três Lagoas.

A territorialização do monocultivo de eucalipto e das indústriais produtoras de celulose e papel, denominado, neste trabalho, como "complexo eucalipto-celulose-papel", está provocando uma série de impactos socioambientais, tais como: dificuldade para o desenvolvimento do campesinato, redução das áreas e das producões das outras atividades agropecuárias, diminuição do número de trabalhadores rurais, homogeneização da paisagem, redução da biodiversidade, desequilíbrio biológico, poluição do ar, da água e do solo em decorrência da utilização de agrotóxicos, dentre outros (KUDLAVICZ, 2011; ALMEIDA, 2012; PERPETUA, 2012). Todavia, o campesinato segue resistindo às adversidades impostas pela territorialização do capital, conforme poderá ser notado no próximo item.

\section{A RESISTÊNCIA CAMPONESA EM TRÊS LAGOAS}

O município de Três Lagoas sempre foi caracterizado pela elevada concentração fundiária, todavia, com a criação de assentamentos da reforma agrária, a partir do início da década de 2000, o número de camponeses passou a crescer consideravelmente. Apesar do recente crescimento do campesinato, a estrutura fundiária ainda é extremamente concentrada na localidade pesquisada, conforme pode ser verificado na Tabela 5.

Tabela 5. Três Lagoas - MS: número de estabelecimentos agropecuários (2006)

\begin{tabular}{lcccc}
\hline Grupos de area & $\begin{array}{c}\text { Número de } \\
\text { estabelecimentos }\end{array}$ & $\%$ & $\begin{array}{c}\text { Área dos } \\
\text { estabelecimentos }\end{array}$ & $\%$ \\
\hline Até 100 ha & 373 & 33,4 & 11.511 & 1,2 \\
Mais de 100 ha & 743 & 66,6 & 933.499 & 98,8 \\
Total & 1.116 & 100 & 945.010 & 100 \\
\hline
\end{tabular}

Fonte: Censo Agropecuário - IBGE (2006).

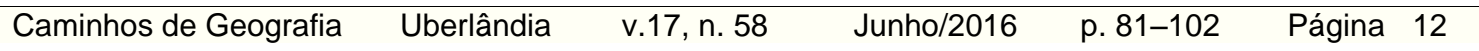


Mesmo com o recente crescimento, a territorialização do complexo eucalipto-celulose-papel é um dos fatores que limita o desenvolvimento do campesinato no município pesquisado. Deste modo, dos 25 camponeses pesquisados de Três Lagoas, 17 (68\%) entendem que a expansão dos eucaliptais se configura como obstáculo para o desenvolvimento de suas atividades no campo (Figura 4).

Figura 4. Três Lagoas - MS: camponeses pesquisados que consideram ou não a expansão do monocultivo de eucalipto como obstáculo para o desenvolvimento de suas atividades no campo

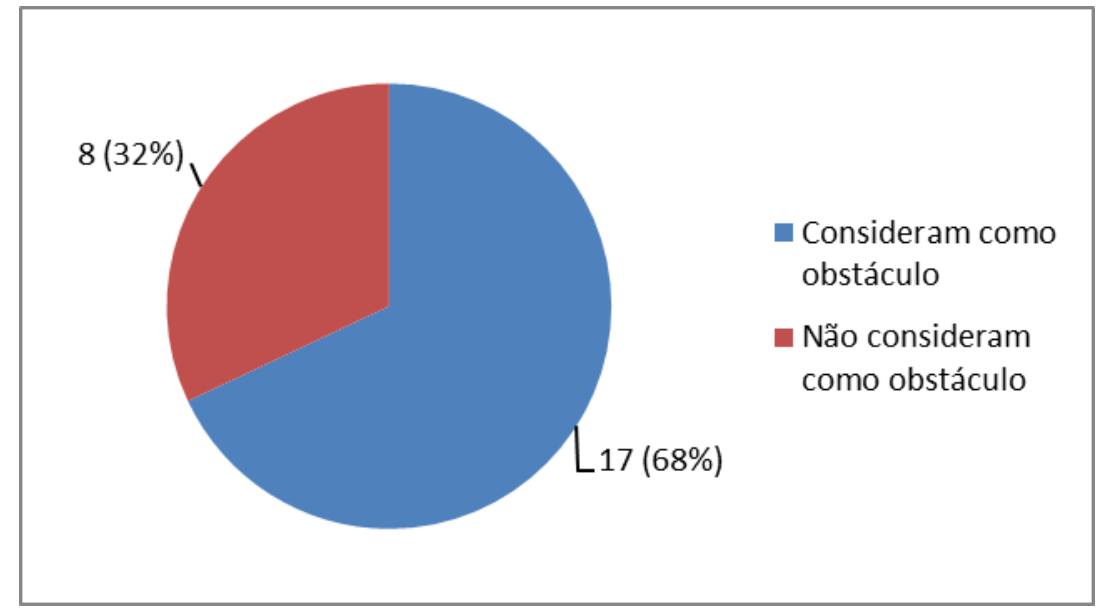

Fonte: Trabalho de campo (2015).

Os camponeses pesquisados, que acreditam que a expansão do monocultivo tem dificultado 0 desenvolvimento de suas atividades no campo, citaram diversos motivos como é o caso da destruição de lavouras devido aos agrotóxicos pulverizados nos eucaliptais, da redução da dinâmica das comunidades rurais, da diminuição do número de trabalhadores rurais e do desequilíbrio biológico. Além destes fatores, os camponeses de Três Lagoas também relataram receio em relação à grande quantidade de água consumida durante o processo de crescimento do eucalipto. Os moradores do Assentamento Pontal do Faia também reclamaram do mau cheiro gerado pela agroindústria da Eldorado Brasil, que está a cerca de 1 quilômetro da entrada do assentamento. Segundo os moradores, o mau cheiro é constante e incomoda muito. Nos relatos camponeses abaixo, podem ser notados os vários impactos causados pela expansão do monocultivo de eucalipto:

Onde tem eucalipto, seca. Ele suga muita água. Também tem o veneno. Pra mim é o maior medo. O veneno é jogado no ar e pode ir pras plantação que tão perto. Eu também acho que mudo o ecossistema. As ema e os tucano tão vindo come aqui. Eu não ligo, não. Eu gosto deles aqui, mas dá dó. Eles têm que vim aqui, porque eles não têm mais onde come por aí. Virou tudo eucalipto. Nos eucalipto não tem alimentos pra eles (N. C. M. M. 09/04/2015).

Eu acho que tá atrapalhando sim! Vejo pela falta de água. Todo mundo fala que o eucalipto usa muita água. Aí se você planta muito eucalipto é lógico que a água vai diminui. Um monte de rio pequeno e açude que tem aqui perto tá ficando sem água. Eu acho que tem a vê, porque antes desse monte de eucalipto, eles sempre tinha água (P. R. F. 09/04/2015).

Antes do eucalipto tinha mão de obra, agora não tem mais. De vez em quando a gente precisa, mas está difícil de acha e quando acha é muito caro. A gente não tem condição de paga. A gente ganha pouco, se tirar pra pagar 
alguém, a gente vai acaba perdeno. Vai trabalha pra não ganha nada (E. S. F. 09/04/2015).

O eucalipto atrapalha muito! Ele puxa muita água. Só tão plantano eucalipto. O resto tá tudo diminuino. O gado, as otra roça, tão tudo acabando. Você só vê eucalipto aqui. Mas, e depois? O povo vai comer o que? O eucalipto não dá pra come (risos) (D. S. S. 09/04/2015).

\begin{abstract}
As coisa tão ficano mais difícil depois do eucalipto. Antes era outra coisa. Era melhor. Até as fazenda de gado era melhor, porque lá morava mais gente. Antes tinha gente nas fazenda. Agora é só eucalipto. Eu vi um monte de sede ser derrubada. Eles passava a máquina e derrubava tudo. Era cada casão bonito. Dava até dó. Eles tiraram tudo as benfeitoria da fazenda. Não sei se isso compensa. $E$ depois pra faze isso tudo de novo? [...] Aí tem um monte de gente que perdeu emprego e teve que ir pra cidade. Diminuiu muita gente na zona rural. [...] Também tem o problema da água. Os açude tá secano. Dá pra perceber isso. Tem os veneno tamém. Tem um monte de coisa ruim pra natureza. É o que eu acho (R. B. 09/04/2015).
\end{abstract}

No último relato, fica evidente que a expansão dos eucaliptais alterou a dinâmica do campo, em Três Lagoas. Essa alteração fica clara, principalmente no Distrito de Arapuá, comunidade rural tradicional de Três Lagoas. Além das reclamações já mencionadas, os camponeses pesquisados relataram que, após a expansão do monocultivo de eucalipto, houve enfraquecimento da dinâmica do distrito, conforme pode ser notado no depoimento do camponês P. R. F.:

[...] também tem o problema aqui do Arapuá. Muita gente foi embora. Quando era a época das fazenda de gado, era diferente. Tinha mais gente aqui. Você ia lá no patrimônio, no final de semana, e tava lotado. Sempre tava cheio. Hoje tá fechando tudo lá. Tinha dois mercado, duas padaria, um monte de coisa. Fechou tudo. O último mercadinho que tinha vai para esse mês. Agora só vai fica os buteco, porque os dono são aposentado, vive mais da aposentadoria, porque senão, eles ia embora também, porque não dá mais pra vive de comércio lá no patrimônio (P. R. F. 09/04/2015).

Alguns camponeses pesquisados (32\%) não consideram a territorialização do complexo eucalipto-celulose-papel como obstáculo para o desenvolvimento de suas atividades no campo. Tal situação ocorre, principalmente em virtude da atuação constante de empresas, como a Fibria e a Eldorado Brasil. Por meio de projetos, a atuação dessas empresas supre a ausência do poder público junto aos camponeses. Assim, alguns pesquisados, mesmo cientes dos impactos socioambientais gerados por essas empresas, as defendem. $\mathrm{O}$ apoio prestado pelas empresas "conquistam" os camponeses, já que este apoio, por parte do poder público, é deficitário.

Em função do recente crescimento do número de camponeses, o próprio município parece não estar pronto para lidar com o campesinato, pois o órgão da Prefeitura de Três Lagoas voltado para atender o setor agropecuário é o Departamento de Agronegócio, que é um dos departamentos da Secretaria de Meio Ambiente, Agronegócio, Ciência e Tecnologia. Assim, fica evidente qual é o foco e a prioridade das ações municipais no que se refere ao setor agropecuário. Destarte, a ausência de apoio por parte do poder público faz com que os programas e projetos desenvolvidos pelas agroindústrias sejam importantes para os camponeses. Fonseca (2014), em sua pesquisa no Assentamento São Joaquim, no município de Selvíria, também notou essa relação:

$\begin{array}{lllll}\text { Caminhos de Geografia } \quad \text { Uberlândia } \quad \text { v.17, n. 58 Junho/2016 } \quad \text { p. 81-102 } \quad \text { Página } 14 & 14\end{array}$


Paradoxalmente, a relação com o monocultivo de eucalipto se mostra contraditória, pois mesmo sendo as próprias empresas de celulose e papel as responsáveis por muitas das dificuldades de produção no assentamento, por outro lado, os assentados entendem como benéfico o trabalho nas plantações de eucalipto e os projetos que as empresas de celulose e papel desenvolvem no assentamento. Os projetos das empresas são para o plantio de lavouras, de hortas, a produção de mel, além de reformas e doações de equipamentos, a construção da escola no assentamento, etc. Os assentados criam uma relação de dependência com as empresas de celulose e papel, visto que impactam diretamente o assentamento, também levam benefícios. Diante disso, os assentados se sentem inseguros e ameaçados na condição de críticos de uma empresa que pode beneficiá-los com o trabalho, ou com um projeto que os ajudem a gerar renda, caso haja uma situação de dificuldade para a família. Foi o que questionou um assentado durante a entrevista: "como vamos cuspir no prato em que comemos?" (FONSECA, 2014, p. 136).

O programa de Produção Agroecológica Integrada e Sustentável (PAIS) é um exemplo da atuação das agroindústrias junto aos camponeses. No Assentamento Pontal do Faia, o PAIS (Figura 5) é desenvolvido com apoio da Eldorado Brasil, que entregou equipamentos necessários para o desenvolvimento do programa, como caixa d'água, sistema de irrigação e instrumentos para para o manejo do plantio.

Figura 5. Três Lagoas - MS: horta do programa PAIS no Assentamento Pontal do Faia

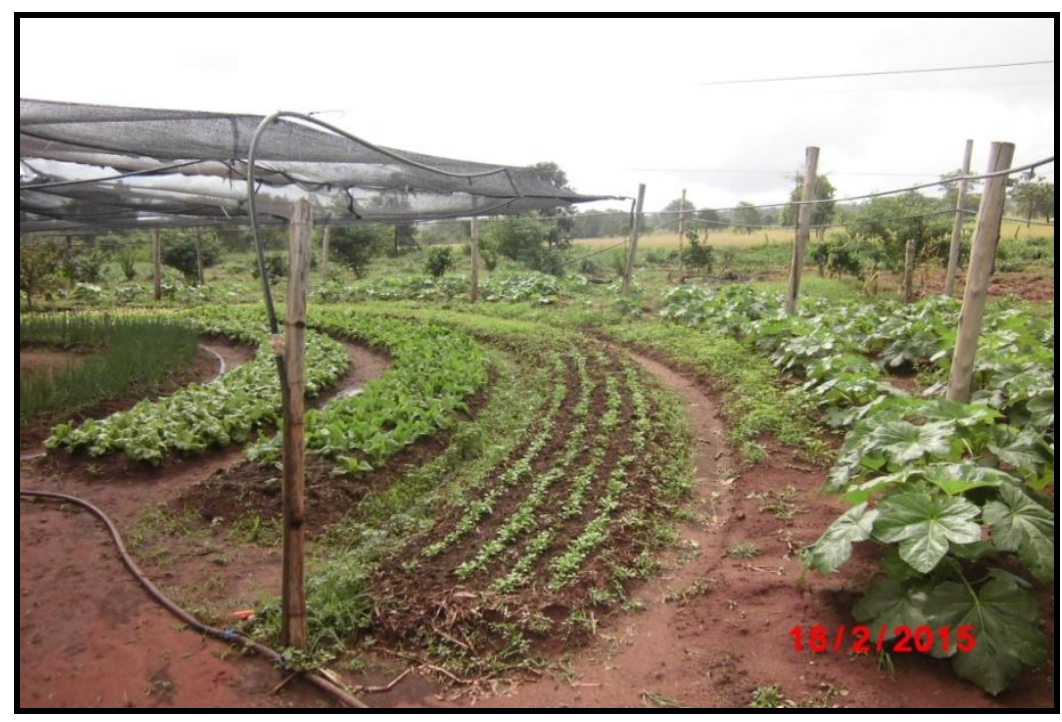

Autor: CARVALHO (2015).

Apesar da atuação constante das agroindústrias produtoras de celulose e papel, alguns camponeses - inclusive os participantes das ações desenvolvidas pelas agroindústrias - não se deixam levar pela influência exercida pelas agroindústrias, como é o caso da camponesa treslagoense N. C. M. M.:

A Fibria tem uns projetos aqui. Ela faz um trabalho social aqui. Diz que é pra ajuda a gente, mas não é isso. Eu sei que é pra "tapa buraco", mas eu não me calo. Eu sei que ela ajuda nos projetos que tem aqui no assentamento, mas eu não tenho medo não. Eu falo mesmo! Eles vêm aqui, fala que tão ajudano, mas não é bem assim. Eu sei que a Fibria tem que ter essa parte. 
Ela não faz isso porque é "boazinha". Ela faz porque tem que fazer (N. C. M. M. 09/04/2015).

Mesmo com as dificuldades enfrentadas para o desenvolvimento de suas atividades no campo, apenas um (4\%) dos 25 camponeses pesquisados de Três Lagoas afirmou a intenção de migrar para a cidade. Enquanto isso, os outros 24 (96\%) (Figura 6) pesquisados pretendem continuar no campo desenvolvendo suas atividades agropecuárias, evidenciando a resistência camponesa perante a territorialização do capital.

Figura 6. Três Lagoas - MS: intenção dos camponeses pesquisados de permanecer ou não no campo

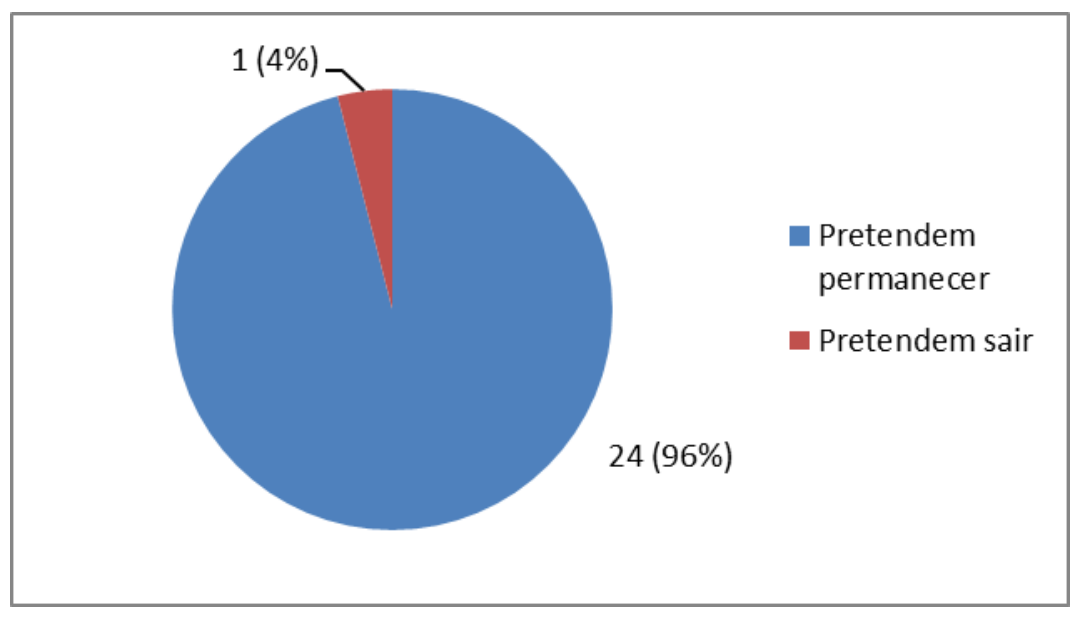

Fonte: Trabalho de campo (2015).

Apesar do contexto desfavorável para o desenvolvimento do campesinato, o camponês treslagoense L. S. foi enfático ao relatar o intuito de permanecer no campo:

Eu sempre morei na roça e daqui eu não saio. Sempre tive uma vida difícil, com muita dificuldade, mas eu sempre tive o que comer. Nunca me faltou nada. Na roça é assim. Não passa fome. Na cidade é outra história. Eu não gosto da cidade. Lá tudo tem que comprar. Aqui a gente planta, colhe... Tá tudo pertinho da gente. Aqui a gente tem fartura. Fome aqui a gente não passa não. A gente planta de tudo um pouco. A gente também tem galinha, porco... Aqui na roça a gente vive bem! (L. S. 10/04/2015).

A respeito da resistência camponesa em Três Lagoas, Kudlavicz (2011, p. 75) afirma:

Apesar da estrutura fundiária da Microrregião de Três Lagoas ser uma das mais concentradas no MS, é nesta região que os camponeses, teimosamente, resistem e insistem em se reproduzir socialmente em meio a toda sorte de adversidades. E ainda respondem por uma percentagem significativa da produção animal e vegetal, apesar da dinâmica da estrutura fundiária e de produção estar baseada, nas últimas três décadas, na monocultura do eucalipto e das pastagens para pecuária.

A combinação de diferentes fontes de renda pelos camponeses de Três Lagoas (Figura 7) é um dos fatores que possibilita a permanência deles e de seus familiares no campo. Essa combinação faz parte das estratégias camponesas para permanecer na terra, resistindo às

$\begin{array}{lllll}\text { Caminhos de Geografia } \quad \text { Uberlândia } \quad \text { v.17, n. 58 Junho/2016 } & \text { p. 81-102 } & \text { Página } 16\end{array}$


adversidades impostas pelo capital. Em Três Lagoas, por exemplo, 17 camponeses (68\%) pesquisados relataram que parte da renda obtida em atividades não agrícolas (aposentadoria, trabalho na cidade e aluguel de imóveis) é utilizada para o desenvolvimento das atividades da unidade de produção camponesa. Essas fontes de renda não agrícolas, muitas vezes, contribuem para a aquisição de adubos e fertilizantes, para o pagamento da prestação de serviços e de melhoria da infraestrutura, entre outras necessidades.

Figura 7. Três Lagoas - MS: principais fontes de renda dos camponeses pesquisados

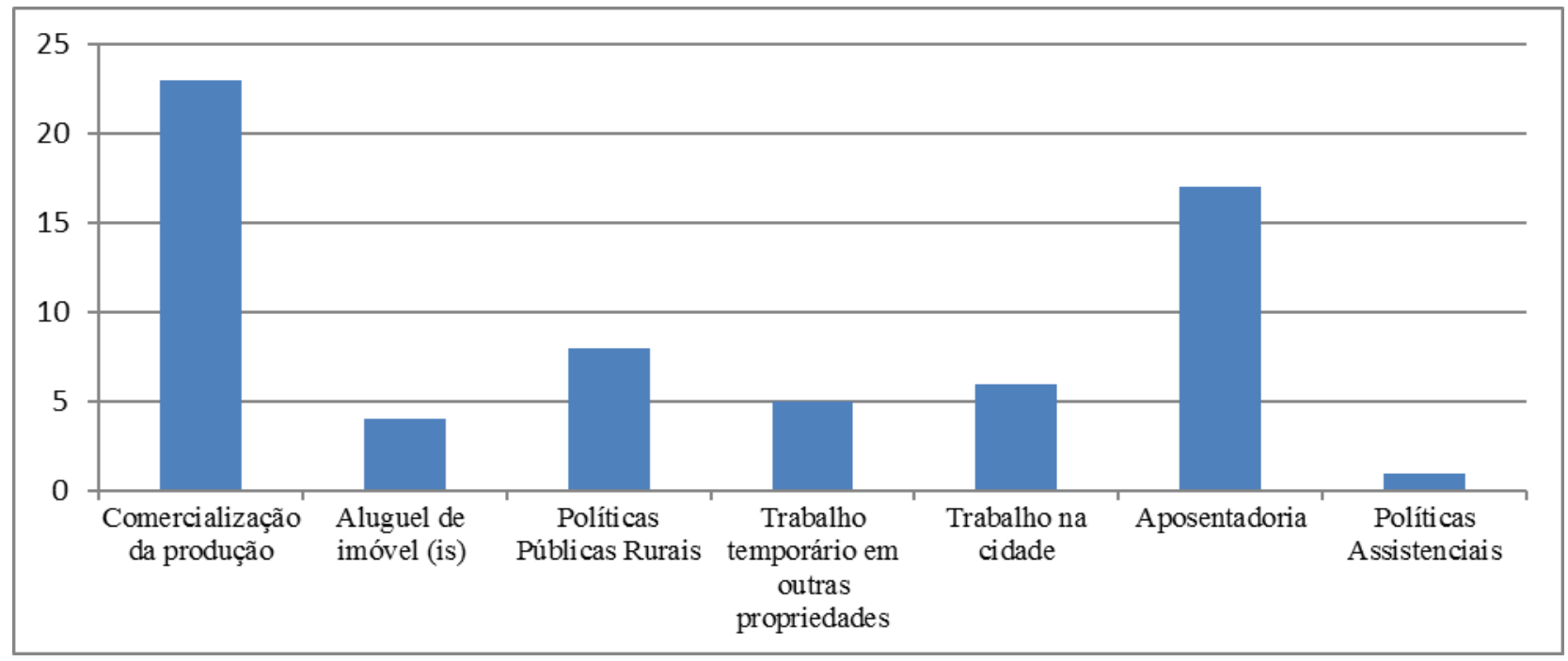

Fonte: Trabalho de campo (2015).

Apesar da importância da combinação de diferentes fontes de renda, os fatores não econômicos, relacionados ao modo de vida camponês, são os principais motivos que influenciam na resistência camponesa (Figura 8). Os fatores mais citados pelos camponeses de Três Lagoas, no que diz respeito à sua permanência no campo, foram: tranquilidade da vida no campo (25), relação de afetividade com o lugar (24), propriedade adquirida por meio de muitos esforços (24), interesse pelo trabalho rural (24), baixo custo da vida no campo (21), proximidade em relação à cidade (15). A qualidade da alimentação e a propriedade fruto de herança foram citadas apenas uma vez. 
Figura 8. Três Lagoas - MS: fatores que influenciam a permanência dos camponeses pesquisados no campo

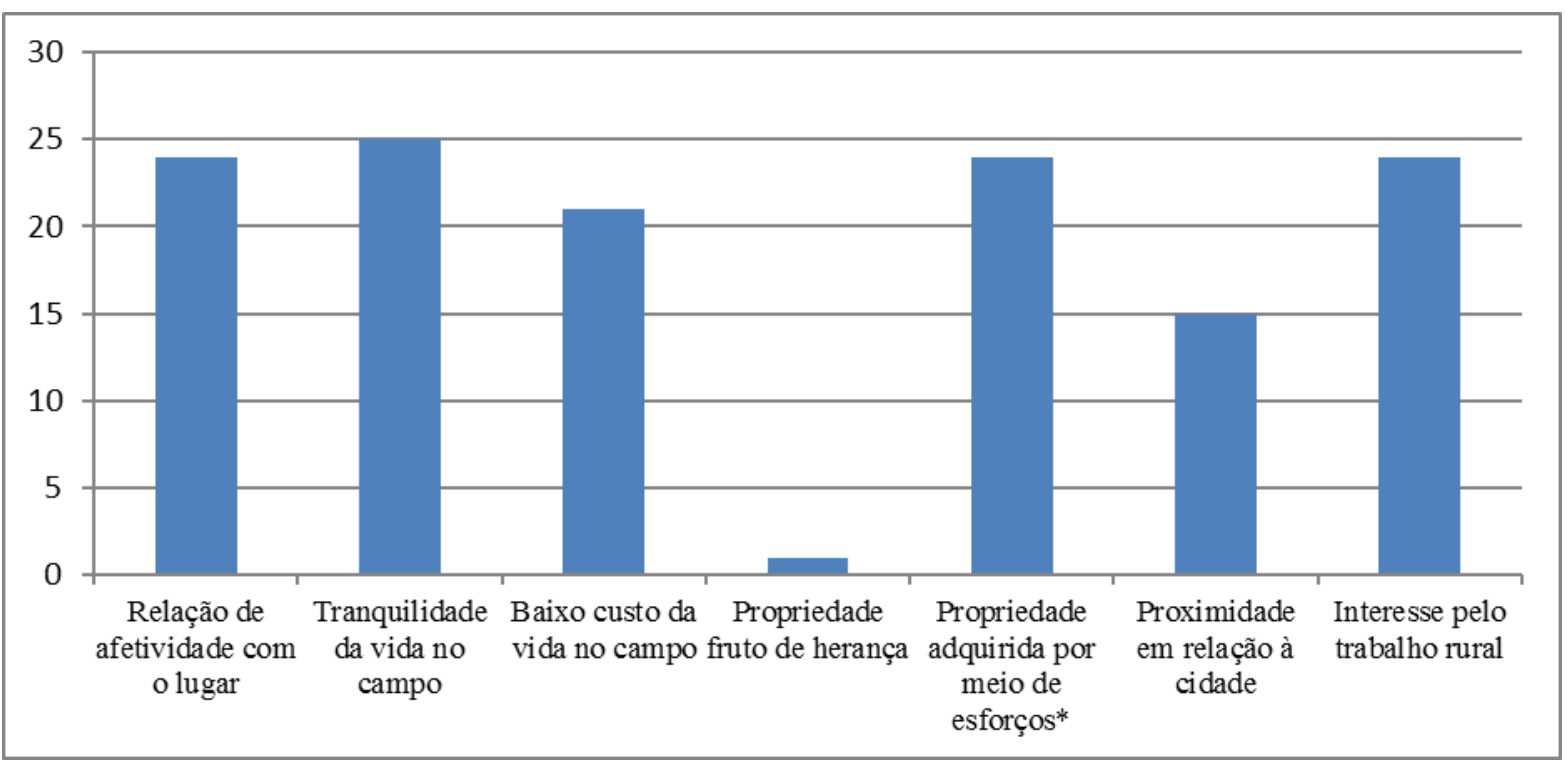

* Inclui os assentados que ainda não são proprietários de fato da terra.

Fonte: Trabalho de campo (2015).

Diversos fatores relacionados à permanência no campo ligada ao modo de vida camponês podem ser observados no depoimento do assentado treslagoense J. P.:

Eu já morei na cidade muitos anos. Aí depois vim aqui pro assentamento. Foi muito difícil pra tá aqui. Foi uma batalha. Passamo muito sufoco no acampamento. Chuva, sol, muita puera, mas eu não me arrependo. Hoje eu vejo que valeu a pena. É muito bom tá aqui. Aqui a gente tem qualidade de vida, de comida... A gente tem uma convivência boa no assentamento, sempre tem reunião. Toda terça tem terço também. O pessoal sempre tá junto [...] Eu não troco aqui por nada. [...] Eu gosto de trabalha na roça. É melhor que trabalha na cidade. Aqui a gente tem mais liberdade pra trabalha do nosso jeito (J. P. 10/04/2015).

Como verificado, os fatores não econômicos, relacionados ao modo de vida camponês, são os principais responsáveis pela permanência dos camponeses pesquisados no campo. Tal situação evidencia o campesinato enquanto modo de vida pautado na tríade terra, trabalho e família (WOORTMANN, 1990; ALMEIDA, 2006). Assim, fica evidente que a utilização da terra pelos camponeses e pelo complexo eucalipto-celulose-papel possuem interesses e resultados distintos. Enquanto a terra ocupada pelos camponeses é terra de trabalho e de reprodução familiar, a terra ocupada pelo referido complexo é terra de negócio, que visa o lucro e proporciona uma série de impactos socioambientais (MARTINS, 1980).

\section{CONCLUSÃO}

A territorialização do complexo eucalipto-celulose-papel no município de Três Lagoas ocorreu em meados da década de 2000 e contou com forte apoio dos governos federal, estadual e municipal, provocando intensa reestruturação espacial, produtiva e econômica, além de diversos impactos socioambientais.

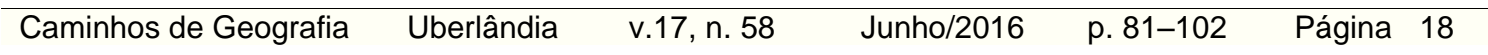


Em função da estrutura fundiária de Três Lagoas, o campesinato nunca foi expressivo no município. No entanto, a partir do início da década de 2000, devido à criação de assentamentos da reforma agrária, o número de camponeses passou a crescer significativamente. Apesar do crescimento do campesinato, os camponeses ainda encontram diversos obstáculos para 0 desenvolvimento de suas atividades no campo, com destaque para a territorialização do complexo eucalipto-celulose-papel. Os camponeses relataram que, após a territorialização do complexo em questão, diversos obstáculos surgiram ou foram ampliados, com destaque para: diminuição do número de trabalhadores rurais, redução da dinâmica das comunidades rurais, desequilíbrio biológico, poluição do ar, da água e do solo, destruição de lavouras devido aos agrotóxicos pulverizados nos eucaliptais e redução da disponibilidade hídrica.

Mesmo com as dificuldades, a grande maioria dos camponeses pesquisados indicou a intenção de permanecer no campo, evidenciando a resistência em relação à territorialização do capital em Três Lagoas. Apesar da importância da combinação de diferentes fontes de renda, os principais fatores viabilizadores da resistência camponesa, em Três Lagoas, não estão relacionados ao âmbito econômico, pelo contrário, são relacionados ao modo de vida camponês, pautado na tríade terra, trabalho e família.

\section{AGRADECIMENTOS}

Agradecemos à Fundação de Apoio ao Desenvolvimento do Ensino, Ciência e Tecnologia do Estado de Mato Grosso do Sul (FUNDECT) por viabilizar financeiramente o desenvolvimento desta pesquisa.

\section{REFERÊNCIAS}

ALMEIDA, R.A. (Re)criação do campesinato, identidade e distinção: a luta pela terra e o habitus de classe. 1. ed. São Paulo: Ed. UNESP, 2006.

Territorialização complexo eucalipto-celulose-papel em Mato Grosso do Sul. Anais XXI Encontro Nacional de Geografia Agrária. Uberlândia, 2012. p. 1-19. Disponível em: $<\mathrm{http} / / / w w w . l a g e a . i g . u f u . b r / x x 1$ enga/anais_enga_2012/eixos/1291_1.pdf>. Acesso em: 14 de janeiro de 2014.

BEDUN, M.R. Os desafios da agricultura familiar camponesa frente à territorialização do agronegócio: perspectivas para o município de Tupi Paulista e seu entorno regional. Dissertação (Mestrado em Geografia). 2012. 138 f. Universidade Federal de Mato Grosso do Sul, Três Lagoas, 2012.

CHAVEIRO, E.F.; CALAÇA, M. Por uma abordagem territorial do Cerrado Goiano. In: SAQUET, M.A.; DANSERO, E.; CANDIOTTO, L.Z.P. (Org.). Geografia da e para a cooperação ao desenvolvimento territorial: experiências brasileiras e italianas. 1. ed. São Paulo: Outras Expressões, 2012. v. 1, p. 191-206.

CALAÇA, M. Territorialização do capital: biotecnologia, biodiversidade e seus impactos no cerrado. Revista Ateliê Geográfico. Goiânia, v. 1, n. 9, fev/2010, p. 6-23. Disponível em: <http://www.revistas.ufg.br/index.php/atelie/article/view/16680 >. Acesso em: 10 de julho 2013.

CANUTO, A. Agronegócio: a modernização conservadora que gera exclusão pela produtividade. Revista NERA. Presidente Prudente, ano 7, n. 5, jul./dez. 2004, p. 1-12. Disponível em: <http://revista.fct.unesp.br/index.php/nera/article/viewFile/1466/1442>. Acesso em: 23 jan. 2014.

Comissão Pastoral da Terra (CPT). Conflitos no campo Brasil (1990 a 2013). Disponível em: $<$ http://www.cptnacional.org.br/index.php/component/jdownloads/viewcategory/43-conflitos-nocampo-brasil-publicacao? ltemid=23>. Acesso em: 12 de janeiro de 2015. 
FABRINI, J.E. O campesinato frente à expansão do agronegócio e do agrocombustível. In: SAQUET, M.A.; SANTOS, R.A. (Orgs.). Geografia agrária, territórios e desenvolvimento. 1. ed. São Paulo: Expressão Popular, 2010, p.55- 88.

. Território, classe e movimentos sociais no campo. Revista da ANPEGE, v. 7, n. 7, p. $\overline{97-112}$, jan./jul. 2011.

FERNANDES, B.M. A Formação do MST no Brasil. 7. ed. Petrópolis, RJ: Vozes, 2000.

Entrando nos territórios do Território. In: PAULINO, E.T.; FABRINI, J.E. (Orgs.). Campesinato e territórios em disputa. 1. ed. São Paulo: Expressão Popular: UNESP. Programa de pós-graduação em geografia, 2008, p. 273-301.

GIRARDI, E.P.; FERNANDES, B.M. Geografia das conflitualidades no campo brasileiro. In: FERNANDES, B.M.; MEDEIROS, L.S.; PAULILO, M.I. (Orgs.). Lutas camponesas contemporâneas: condições, dilemas e conquistas. v. 2. São Paulo: Ed. UNESP; Brasília, DF: Núcleo de estudos Agrários e Desenvolvimento Rural, 2009, p.339-366.

Instituto Brasileiro de Geografia e Estatística (IBGE). Produção da Extração Vegetal e da Silvicultura (1990 a 2013). Disponível em <http://www.sidra.ibge.gov.br> Acesso em: 25 de fevereiro de 2015.

JURADO, F.L.S. O processo de industrialização na cidade de Três Lagoas (MS): discursos, desdobramentos e contradições. 2008. 220 f. Dissertação (Mestrado em Geografia). Universidade Federal de Mato Grosso do Sul, Aquidauana, 2008.

KUDLAVICZ, M. Dinâmica agrária e a territorialização do complexo celulose/papel na microrregião de Três Lagoas/MS. 2011.177 f. Dissertação (Mestrado em Geografia). Universidade Federal de Mato Grosso do Sul, Três Lagoas, 2011.

LIMA, J.R. Contradições na produção do espaço rural brasileiro: modernização do campo, espacialização da pobreza e resistência. Revista GeoNordeste. Ano XXIII, n. 1, p. 136-156, 2012.

<http://200.17.141.110/pos/geografia/geonordeste/index.php/GeoNordeste/article/view/274>. Acesso em: 12 de julho de 2013.

MARTINS, J.S. Expropriação e Violência: a questão política no campo. São Paulo: Hucitec, 1980.

MATOS, P.F.; PESSÔA, V.L.S. Territorialização da agricultura moderna na região da estrada de ferro (Goiás) e as modificações no espaço agrário. XIX Encontro Nacional de Geografia Agrária. São Paulo, 2009, p. 1-18. Disponível em: <http://www.geografia.fflch.usp.br/inferior/laboratorios/agraria/Anais\%20XIXENGA/artigos/Mato s_PF.pdf>. Acesso em: 15 de julho de 2013.

A modernização da agricultura no Brasil e os novos usos do território. RevistaGeo UERJ. Ano 13, n. 22, v. 2. p. 290-322, 2011. Disponível em: <http://www.epublicacoes.uerj.br/index.php/geouerj/article/view/2456>. Acesso em: 15 de junho de 2014.

OLIVEIRA, A.U. Modo Capitalista de Produção e Agricultura. 4. ed. São Paulo: Ática, 1995.

A agricultura camponesa no Brasil. 2. ed. São Paulo: Contexto, 1996a.

Agricultura Brasileira: Transformações Recentes. In: ROSS, J.L.S. (Org.), Geografia do Brasil. São Paulo: Edusp, 1996b. p. 467-534.

Edições, 2007.

Modo de Produção Capitalista, Agricultura e Reforma Agrária. São Paulo: Labur

PAULINO, E.T.; ALMEIDA, R.A. Terra e território: a questão camponesa no capitalismo. 1. ed. São Paulo: Expressão Popular, 2010.

PERPETUA, G.M. A mobilidade espacial do capital e da força de trabalho na produção de celulose e papel: um estudo a partir de Três Lagoas (MS). 2012. 251 f. Dissertação (Mestrado em Geografia). Universidade Federal da Grande Dourados, Dourados, 2012.

$\begin{array}{lllll}\text { Caminhos de Geografia } \quad \text { Uberlândia } \quad \text { v.17, n. } 58 \quad \text { Junho/2016 } & \text { p. 81-102 } & \text { Página } 20\end{array}$


PORTO-GONÇALVES, C.W. Geografia da riqueza, fome e meio ambiente: pequena contribuição crítica ao atual modelo agrário/agrícola de uso dos recursos naturais. In: OLIVEIRA, A.U.; MARQUES, M.I.M. (Orgs.). 0 campo no século XXI: território de vida, de luta e de construção da justiça social. São Paulo: Editora Casa Amarela e Editora Paz e Terra, 2004. p. 207-253.

THOMAZ JÚNIOR, A. Dinâmica Geográfica do Trabalho no Século XXI: Limites Explicativos, Autocrítica e Desafios Teóricos. Presidente Prudente, São Paulo, 2009.

WOORTMANN, K. "Com parente não se neguceia". O campesinato como ordem moral. Anuário Antropológico. Brasília: DAN/UNB, 1990, p. 11-73. Disponível em: $<$ http://www.dan.unb.br/images/pdf/anuario_antropologico/Separatas1987/anuario87_woortman n.pdf >. Acesso em: 12 de dezembro de 2014 . 